\title{
1.6 Features of formation of civic competencies of junior schoolchildren in the system of training of future primary school teachers in higher education institutions
}

One of the priority areas of work in a modern school is civic education - the process of forming a conscious citizen, a person with such qualities and character traits, worldview and way of thinking, feelings, actions and behavior, which are aimed at developing civil society in Ukraine. Every educator today clearly understands the need to create such an environment in secondary schools, in higher education institutions, where human rights and children's rights would be considered as a pedagogical direction, because students must learn democracy through school experience.

Ensuring the formation of civic competence in the modern content of primary school education is carried out through educational programs that provide four crosscutting content lines - environmental security and sustainable development, civic responsibility, health and safety, entrepreneurship and financial literacy. In particular, the cross-cutting line "Civil Responsibility" ensures the development of social and civic competencies, reveals the essence of the concept of "responsible citizen", defines the vectors of its activities [52, p. 3].

Teachers often have some difficulties in implementing curricula. The difficulty is that we need to develop and use tools to, without overloading children with a huge amount of additional information (because the programs are already saturated), to form in them the skills, attitudes and values needed by citizens, because if we want to form a new citizen, we must understand that this person must not only have knowledge, skills of a general nature, but he must clearly position himself in society, understand what it is, be able to interact in society and be an active member. That is why this industry is very important now. In our opinion, it is leading if we want to achieve not only a new quality of education, but also a new quality of society.

The relevance of this research topic is defined in the Constitution of Ukraine (1996), in the "Recommendations of the European Parliament and the Council of Europe" "On core competencies for lifelong learning" (2016), the Council of Europe Charter on Education for Democratic Citizenship and Human Rights (2017), in the Law 
of Ukraine "On Education" (2017), in the "Concept of Civic Education" (2016), in the Concept "New Ukrainian School" (2016), school curricula. I. Bekh, V. Kuz, O. Zakharenko, V. Sukhomlynsky, O. Sukhomlynska, O. Semenog, G. Shevchenko study the problem of formation of civil responsibility of students, value attitude of the person to language, culture, democracy, the state, civil rights and freedoms, G. Filipchuk and others. [53, p. 30].

To a large extent, the issue of forming the personality of a citizen who adheres to civic duty, is tolerant of other people's opinions, respects national history, culture and the culture of other peoples, takes an active part in social processes relevant to modern primary school. The role of Ukrainian language lessons and reading is important in the formation of civic responsibility, because "it is through language," $\mathrm{T}$. Usatenko rightly remarks, that the self-consciousness and self-awareness of the people themselves as a nation grows; such a nation becomes self-sufficient" [54, p. 3].

Based on the concept of the "New Ukrainian School" and the recommendations of the Council of Europe in the field of education for democratic citizenship and human rights, the reform of the Ukrainian school lays radically new approaches to the educational process.

The State Concept of Civic Education states that the defining feature of a person should be citizenship. Citizenship is a person's willingness to exercise their rights and responsibilities, to respect the rights and freedoms of other citizens, to understand the responsibility to society and the state for their actions. Obviously, this understanding allows us to define it as a psychological trait, a characteristic of personality. Civic competence by researchers is one of the key ones. Therefore, the civic competence of the primary school student, we will understand as a set of educational elements, consisting of a set of knowledge, skills, experiences, emotional and value orientations, personal beliefs that help people realize their place in society, duty and responsibility to compatriots, homeland and state [54, p. 74].

O. Pometun notes that the components of the structure of civic competence of junior students are three components: value (attitude, value orientations, experiences), 
activity (skills) and procedural or personal-creative (concerning the sphere of selfrealization) [53, p. 30].

Each of the components can be represented as an integrated quality of personality. That is, the school should consist not only of knowledge, but of the ability to apply this knowledge in practical situations, for personal and professional development, as well as to apply values that help to navigate in the modern information space. This requires a new content of education, new teaching methods, a new educational environment. Therefore, in the process of learning the Ukrainian language, reading lessons, the development of social and civic competencies can occur through learning at three levels: learning "learning about...", "learning to develop understanding and attitudes", as well as "learning through experience" [55, p. 45].

The formation of civic competence in the modern content of primary school education aims to promote the formation of a system of democratic civic education in Ukraine through the dissemination of European experience, to bring Ukraine closer to the European educational, socio-political, economic and legal space. To bring up a student's civic competence means to form in him a set of personal qualities and character traits, which is the basis of a specific way of thinking and the motivating force of everyday actions, deeds, behavior [52, p. 77].

This is patriotic self-awareness, civic responsibility and courage, readiness to work for the development of the state, to defend it, to raise international prestige. It is respect for parents, their pedigree, traditions and history of the native people, awareness of their independence as its representative, heir and successor. This is discipline, diligence, perseverance, creativity, a sense of caring owner of their land, care for its nature, ecology. These and other qualities and traits are formed in the process of assimilation by junior students of the spiritual heritage of the native people, purposeful national education as a system of ideas, views, beliefs, traditions, customs and other forms of social policy of the Ukrainian people, natural and historical development of material and spiritual culture of the nation. 
Thus, civic education is based on the ideological richness of the people, their moral and ethical values, educational wisdom, which is transformed in their pedagogical experience. In order for children to become a nation, creators of their destiny, it is necessary that during their studies, upbringing in the family, school, they firmly assimilate the history of their state, spirituality, culture of the native people, deeply imbued with its national spirit, way of thinking and living. [50, p. 67].

Formation of communicative competence is one of the main tasks of formation of a person adapted to modern conditions. This competence is formed in terms of direct interaction, so it is the result of communication experience.

To form the communicative competence of junior schoolchildren in practical classes on the methods of teaching the Ukrainian language for primary school students, higher education students were offered different types of speech activities: listening, writing, speaking, reading. Developed the ability to conduct a proper educational dialogue. They practiced dialogic expressions of different nature: dialogue-exchange of ideas, dialogue-questioning, dialogue-motivation, dialogue of etiquette character. We consider situational tasks that were used in a certain sequence taking into account the topic, content, stage of the lesson, and class readiness to be an effective means of forming communicative competence.

The program material of Ukrainian language lessons in 4th grades, during which the requirements of the school curriculum provide for the teaching of syntax on the basis of personality-oriented, activity and competence approaches, allowed to more successfully form behavioral norms in junior students to solve life problems; ability to convincingly express one's own opinion, to lead a reasoned controversy; respond by language to a range of social and cultural phenomena, prevent and resolve conflicts, reach compromises; to adapt to new conditions, to solve non-standard problems; work in a group, in a team.

Among the main tasks were: creating an emotionally comfortable learning environment for literacy, developing the ability of each individual to realize responsibility for their learning, the need to acquire the program knowledge, skills and abilities that were important for forming a communicatively competent person. 
For example, some components of civil responsibility are presented in Volodymyr Monomakh's "Teaching Children", which emphasizes obedience to the law: "do not be jealous of those who commit lawlessness, because the villains will be exterminated" and in the works of Feofan Prokopovich, who argued that respect for the state it is important to use the Word of God, "because when the state is weak, and therefore the law, then there is another law hidden deep in the heart of man" to love and fear God, to save his life - not to do to others what you do not want, to honor your father and his mother" [53, p. 134].

Ukrainian philosopher, poet, pedagogue and educator Hryhoriy Skovoroda and Taras Shevchenko defended the ideas of democracy, freedom, philanthropy and charity, patriotism. He defined the freedom, liberty and independence of Ukraine as the highest value: Great ruin, unravel, fraternize, do not look for in another's land, do not ask what is not in heaven, and not only in another's field. In his house his truth, and strength, and will" [54, p. 234].

Analyzing the curriculum in the Ukrainian language for primary school (textbooks M. Bilchuk, A. Savchuk, G. Sapun), we stated that much attention was paid to the content line "Civil Responsibility". In particular, it is planned to study the following topics in the lessons: Ukraine is a European state; Ukrainian language and problems of bilingualism in Ukraine, multilingualism; history and modernity lessons; the earth is our common home; Ukrainian ideal: traditional and modern understanding; friendship, love, family, intergenerational relationships, culture. For example, the topic "Language is the most important means of communication, cognition and influence" was aimed at teaching younger students to understand and respect human rights and freedoms, to be able to explain their position on human rights, to realize that human rights are the basis for everyone to live with dignity. find ways to solve socially important issues, the ability to argue and competently express their own opinions.

For the 4th grade, more global issues were proposed for consideration, including: Ukraine on the world map; Constitution of Ukraine, language rights and responsibilities of citizens; history pages. For example, while studying the topic "Text as a unit of speech and a product of speech activity" they had to learn to show interest 
in the promotion of human rights, to express judgments about people in need of special protection. Exercises and tasks were characterized by traditional categories (history of the Ukrainian people and the formation of its statehood; language as a characteristic feature of self-identification of Ukrainian society; customs and traditions as an integral part of the nation's identity; love for the native land through the prism of art; Ukraine through prominent figures; symbols of the Ukrainian people - its national sign), and taking into account the requirements of the Concept "New Ukrainian School".

As the analysis shows, the texts for exercises and tasks in the category "History of the Ukrainian people and the formation of its statehood" in textbooks for 4th grade (O. Davydova, O. Danylko) are based on information about the history of Ukrainian society, historical stages of Ukrainian national identity. Such tasks were quite relevant, they contributed to the understanding of younger students of the history of their people, the origins of Ukrainian statehood and the formation of an independent conciliar Ukraine.

The category "Language as a characteristic feature of self-identification of Ukrainian society" contained exercises and tasks, which revealed the meaning of the Ukrainian language in a broad and narrow sense; the place of the native language in the life of society, the means of its enrichment and preservation for further development. The exercises presented in the textbook formed in students admiration for the beauty of the native language, its melodiousness, the breadth of use of artistic means in the text.

The category "Love for the native land through the prism of artistic creativity", as evidenced by the analysis of textbooks M. Bilchuk, O. Danylko contains samples of texts of artistic creativity (Song of Baida), journalism (excerpt from the works of V. Sukhomlinsky), in which the beauty of the native land reveals love for the native land, a sense of civic duty to their state, respect, respect for their homeland.

The category "Ukraine through the eyes of prominent figures" includes texts about famous historical figures of our country: writers, public figures, artists, sculptors, musicians and more. Textbooks A. Savchuk, G. Sapun for 4th grade contain exercises based on work with a journalistic text (for example, a text about Taras Shevchenko). 
The category "Symbols of the Ukrainian people - its national sign" is presented, in particular, in the textbook by S. Yermolenko, V. Sychova with texts about the national flag and coat of arms, bird symbols (swallow as a symbol of prosperity and happiness). Thus, textbooks on Ukrainian language and reading for primary school generally contain a source base for learning about the Ukrainian language as the state language of the Ukrainian people, a defining feature of our state, a treasury of cultural heritage of the nation and humanity, a means of interpersonal and interethnic communication, state symbols and values; cultural and spiritual values of Ukrainian and other peoples, the essence of civil society, democracy, rights, freedoms and responsibilities of man and citizen.

We believe that the primary school has ample opportunities for civic education of students. Civic education should be at the heart of all school activities, both in the learning process and in extracurricular activities.

Extracurricular activities are less regulated than educational activities, which makes it possible to vary its content, organizational forms and methods. We note that in extracurricular educational work effective forms of civic education. Its effectiveness depends primarily on the actual recognition by teachers of the student's personality as the main goal of education, the most important priority, the greatest primary school students are: educational hours; historical window; traditional and family holidays; dictionary box; folk wreath; grandmother's tale; Cossack entertainment; quizzes; competitions of national dishes, songs, dances, clothes; competitions of drawings, products from a natural material; club classes; educational and cognitive excursions to the regional museum of local lore, etc.

In the course of the research it was determined that one of the effective means of civic education of junior schoolchildren is local lore work. According to the practice of primary school, direct acquaintance of junior schoolchildren with historical and memorable places of the native land, with its nature, outstanding people, participation of schoolchildren in campaigns and excursions, collection and registration of materials about heroes and their feats, meetings with veterans, discussion books about significant historical events - all this contributes to the education of citizenship of primary school 
children. Thus, it is through local lore that the systemic ideas of junior schoolchildren about their native land, historical and cultural environment are formed.

Homeland studies begins with local lore - historical, ethnographic, geographical, folklore, literary. Taking an active part in the multifaceted local lore work, children from early school age join the heroics of past eras, labor exploits, deeds and artistic traditions of grandparents and great-grandparents.

Complex comprehensive local lore work allows to study and holistically perceive the national color of the native land: the original way of life of Ukrainians, their style of behavior, original way of thinking, art, national psychology, etc. Local lore activities create conditions for students to deeply master the regional features of national life (ethnographic, folklore, language, etc.). Due to this, younger students are deeply aware of themselves as part of the people, they cultivate a love for their home village, city, and region.

Prominent figures, famous people who are patriotic, able to overcome life's difficulties and go to their own goal - become a model for students to develop their own life strategies.

K.D. Ushinsky in his works, defines that true love for the Motherland must be combined with knowledge of language, art, the best traditions and customs of the people [51].

The native language is the best expression of the spiritual culture of the Ukrainian people. The child, mastering the language of his parents, joins the native culture, by means of which the "root of spirituality" is formed. [52] In the article "Native word" Ushinsky wrote about the importance of the native language: blooms again, the color of his whole spiritual life, which begins far beyond history. The language inspires the whole nation and its entire homeland "[51].

S. Rusova noted: "All education - should be national, grow on the native land, among the native language" [52].

Therefore, an important component of the content of civic education is love and respect for the native Ukrainian language, understanding the need for perfect command of the state language. 
The foundations of patriotism and a sense of national belonging and consciousness are laid in the family. The interaction of educational influences of the family and the school is important. Therefore, we note that it is necessary to constantly maintain close ties with parents, to involve parents in the school life of children. Creative cooperation of parents, children and teachers has a positive effect on the formation of the class team, the education of students in humanity, respect for elders, a friendly attitude to peers. The purpose of the article is to form a person with a deep sense of their roots, family, family, people; in the development of the best mental traits of the child, in the awakening of interest and instilling a deep love for the native language, literature, history, respect for the symbols, traditions and customs of Ukrainians.

Thus, civic education in the modern educational process of primary school is extremely important. The full formation of the personality of a junior schoolchild cannot be positively realized without a civic basis. Today it is more important than ever to direct children to choose civic - national ideals and value orientations in their lives. Comprehensive education of the growing personality in our time does not make sense without the civic component.

Conclusions. Our time is a time of radical changes in society. Right now Ukraine needs citizens who are able to make non-standard decisions, to solve various problems; citizens with well-developed critical thinking, who know how to work creatively. Therefore, we consider it necessary to form the social competence of primary school students in Ukrainian language and reading lessons. And given that the influence of the teacher's personality on the formation of students' life competence is special, we clearly understand that the teacher must work effectively, improve professionally and grow creatively, because the teacher is not only the one who teaches all his life, but also the one who learns all his life.

In this context, the use of material on patriotic self-awareness, civic responsibility in the educational process of a modern institution of higher pedagogical education in practical classes on the methodology of the Ukrainian language and reading in primary school is considered quite effective, as it involves research activities of higher 
education students. development of creativity, initiative, critical thinking, independence, self-control, personalization of learning, prevents and helps to overcome the alienation of students from the educational process, helps to build their individual educational trajectories in the educational space. 